Submitted to

Toxicology In Vitro

July 28, 2014

\title{
Antibiotics delay in vitro human stem cell regrowth
}

\begin{abstract}
Melinda Turani ${ }^{1}$, Gaspar Banfalvi ${ }^{1}$ * Agota $\operatorname{Peter}^{1}$, $\operatorname{Krisztina~Kukoricza~}^{1}$, Gabor Kiraly ${ }^{1}$, Laszlo Talas ${ }^{1}$, Bence $\operatorname{Tanczos}^{1}$, Balazs Dezso ${ }^{2}$, Gabor Nagy $^{1 \dagger}$ and Adam Kemeny-Beke $3^{\dagger}$
\end{abstract}

${ }^{1}$ Department of Microbial Biotechnology and Cell Biology, Faculty of Science, University of ${ }^{2}$ Debrecen 4010, Department of Pathology, University of Debrecen 4012, and ${ }^{3}$ Department of Ophthalmology, Faculty of Medicine, University of Debrecen 4012, Hungary

${ }^{\dagger}$ The last two authors contributed equally to this study.

\section{*Correspondence:}

Prof. Gaspar Banfalvi PhD, DSc

University of Debrecen, Department of Microbial Biotechnology and Cell Biology

Life Sciences Building 1.102, 1 Egyetem Square, Debrecen 4010, Hungary

Tel. (36) 52512900 ext. 62319; Fax: (36) 52512925

Email: bgaspar@unideb.hu 


\section{ABSTRACT}

Stem cell line from human limbal area was established to study in vitro cell growth and response to the toxic effects of antibiotics used in ophthalmology in terms of cell migration rates and structure of interphase chromatin. Recovery from cellular damages caused by ophthalmologic antibiotics was mimicked by an in vitro scratch model and followed by time-lapse microscopy, scanning electronmicroscopy and chromatin image analysis. Experiments revealed that broad spectrum antibiotics, chloramphenicol (0.5 $1.0 \mathrm{mg} / \mathrm{ml})$ and rifampicin $(0.1-0.2 \mathrm{mg} / \mathrm{ml})$, corresponding to concentrations in common clinical practice, slowed down the regeneration process. Results show that nuclei of naturally occurring limbal cells contain the same intermediates of chromatin condensation as seen in mammalian tumor cells and follow the common pathway of chromosome condensation. These intermediates included decondensed veil-like chromatin, fibrillary chromatin, supercoiled ribbon, chromatin bodies, early linear forms and metaphase chromosomes. Upon chloramphenicol and rifampicin treatment characteristic distorsions took place in the intermediates of chromosome condensation. Damaging effects in limbal stem cells in the presence of chloramphenicol or rifampicin indicate that ophthalmologic treatment with antibiotics should be used cautiously.

Keywords: Time-lapse imaging; Fluorescent microscopy; Scratch wound mode 1; Chromatin condensation; Toxicity of antibiotics 


\section{Introduction}

The cornea transmitting the light to the retina is covered by epithelial cells and surrounded by a narrow band of limbal cells. Similarly to other epithelia, the epithelium of the cornea is maintained by stem cells that migrate on the corneal surface centripetally as differentiated cells (Kinoshita et al., 1981; Tseng, 1989; Sun et a., 2010). Stem cell population for the corneal epithelium is located at the area known as limbus forming a narrow zone between the cornea and the bulbar conjunctiva and the sclera and mediate corneal renewal and repair (Secker and Daniels, 2009). (Fig. 1). The highest clonogenicity, a feature of limbal stem cells, is found in the smallest keratinocytes. The diameter of these small cells located in the limbal basal epithelium is $10.1+/-0.8 \mu \mathrm{m}$ (Romano et al., 2003). This limbal stem cell population is responsible for the renewal of the corneal epithelium. Loss of limbal function may result in painful blindness (Ahmad, 2012). The isolation of limbal stem cells remained a challenging task due to their colony forming potential, restricted availability of donor corneal tissue for corneal renewal and repair and by the low probability of survival of grafted tissue upon keratoplasty (Majo et al., 2008; Albert et al., 2012). The clonal growth of limbal stem cells was stimulated by fetal bovine serum (Kruse and Tseng, 1993), but presented the risk of transmission of animal-borne viruses or aquisition of antigenic substances on the cell

membrane during culturing limbal stem cells (Baylis et al., 2011; Shortt et al., 2007). The risks of cultivating cornea limbal epithelial stem cells have been eliminated by animal material-free medium (Albert et al., 2012). Beside the possibility of rejection of transplanted limbal cells, during the wound healing there is a further considerable risk, namely the infection, which is normally minimized by autologous serum, prophylactic topical antibiotics, steroid and nonsteroid eyedrops (Dua et al., 2010). Oral steroids and oral cyclosporin were used to prevent rejection and graft failure after penetrating keratoplasty (Frucht-Pery et al., 1988). 
After limbal stem cell transplantation topical forms of corticosteroids, e.g. betamethasone $0.1 \%$ eye drops and ointments, antibiotics such as $0.5 \%$ chloramphenicol drops (Kheirkhah and Karimian, 2010) or chloramphenicol with prednisolone $0.5 \%$ eyedrops have been used (Dua and Azuara-Blanco, 2000). Among the semisynthetic antibiotics, rifampicin has been applied as a $1 \%$ ointment to prevent the growth of Chlamydia trachomatis and lymphogranuloma venerum (Fraunfelder, Meyer, 1982) through the inhibition of DNAdependent RNA polymerase (Becker, 1972; Becker et al., 1970). Data regarding the cellular toxicity of antibiotics are scarce. Thus, before their medical use it is reasonable to test and compare the in vitro damaging and beneficial balance of antibiotics.

In this paper we describe the isolation of limbal stem cells for in vitro toxicological tests. Limbal cells were obtained as a small part of the limbal collar that was subjected to cornea transplantation and regeneration. From the primary culture human limbal stem cell line $(\mathrm{Hu} / \mathrm{Li})$ was established consisting of immortal cells. The cell growth and regeneration process of limbal stem cells was tested in the presence of two broad spectrum antibiotics, chloramphenicol $(0.5-1.0 \mathrm{mg} / \mathrm{ml})$ and rifampicin $(0.1-0.2 \mathrm{mg} / \mathrm{ml})$. Structures of condensing chromosomes of stem cells have not been isolated earlier. Chromatin structures of healthy limbal cells resembled closely to other mammalian tumor cells visualized earlier (Banfalvi et al., 2006). Genotoxicity specific chromatin changes induced by antibiotics caused the delayed regeneration of the damaged limbal cell monolayer.

\section{Materials and methods}

\subsection{Materials}

DABCO (1,4-diazobicyclo-(2,2,2)-octane), chloramphenicol, rifampicin, PenicillinStreptomicin-Neomicin antibiotics (PSN-375963) were from Sigma-Aldrich, Budapest, Hungary. 2,6- diamino-2-phenylindole (DAPI) was the product of Braunschweig Chemie 
(Braunschweig, Germany). Dextran T-150 was purchased from Pharmacia-Biochemicals (Uppsala, Sweden). Colcemid (N-methyl-N-deacetyl-colchicine) was the product of Boehringer (Mannheim, Germany). The molecular formula of chloramphenicol is $\mathrm{C}_{11} \mathrm{H}_{12} \mathrm{Cl}_{2} \mathrm{~N}_{2} \mathrm{O}_{5}$, chemical name: $\quad$ D-threo-(-)-2,2-Dichloro- $N$-[ $\beta$-hydroxy- $\alpha$ (hydroxymethyl)-p-nitrophenethyl] acetamide, molecular weight: $323.13 \mathrm{D}$. The chemical formula of rifampicin is (3-(4-Methyl-piperazinyliminomethyl)-rifamycin), molecular formula: $\mathrm{C}_{43} \mathrm{H}_{58} \mathrm{~N}_{4} \mathrm{O}_{12}$, molecular weight: 823.0 D. Rifampicin is a naphthohydroquinone spanned by an aliphatic ansa chain (Tomiyama et al., 1996). In an attempt to eliminate bacterial contamination, PSN antibiotics were used as a sterile-filtered solution containing penicillin, streptomycin and neomycin. PSN antimicrobial antibiotics are distinguished from ophthalmic antibiotics (chloramphenicol, rifampicin). Antibiotics in this publication refer to chloramphenicol and rifampicin, unless otherwise noted.

Sterile stock solutions of antibiotics, $5 \mathrm{mg} / \mathrm{ml}$ chloramphenicol in physiological saline and $1 \mathrm{mg} / \mathrm{ml}$ rifampicin in sterile physiological saline were obtained from the Pharmacy of Medical Center, University of Debrecen, prepared according to the Formulae Normales Edition VII, National Institute of Pharmacy, Budapest. Further dilutions from stock solutions were made with Dulbecco's Modified Eagle's Medium Nutrient Mixture (DMEM-HAM'S F12) (Sigma-Aldrich, Budapest, Hungary) supplemented with $2 \mathrm{mM}$ L-glutamine, $23 \mathrm{mM}$ sodium bicarbonate, 10\% Fetal Bovine Serum (FBS) and 1\% PSN. Fetal bovine serum and collagenase type IV (160 units/mg) were bought from GIBCO BRL, Life Technologies (Gaithersburg, MD). Collagenase is a unique protease with the ability to degrade the triplehelical native collagen fibrils commonly found in connective tissue such as skin and other epithelial tissues and is preferentially used in stem cell technology. Betadine antiseptic solution (Povidone-iodine, $10 \%$, topic solution, equal to $1 \%$ available iodine) was obtained from Egis Pharmaceuticals PLC, Budapest, Hungary. Eusol-C corneal storage medium containing $143 \mu \mathrm{g} / \mathrm{ml}$ gentamicin was the product of Alchimia SRL, Padova, Italy. 
Antifade Medium consisted of 90\% glycerol, 2\% (w/w) DABCO, 20 mM Tris-Cl, pH 8.0, $0.02 \%$ sodium azide and $25 \mathrm{ng} / \mathrm{ml}$ DAPI for blue fluorescent total staining of DNA. Hypotonic Buffer for reversible permeabilization contained 9 mM HEPES, pH 7.8, $5.8 \mathrm{mM}$ dithiothreitol, 4.5\% dextran T-150, $1 \mathrm{mM}$ EGTA and $4.5 \mathrm{mM} \mathrm{MgCl}_{2}$. Swelling Buffer consisted of $50 \mathrm{mM} \mathrm{KCl}, 10 \mathrm{mM} \mathrm{MgSO}_{4}, 3 \mathrm{mM}$ dithiothreitol and $5 \mathrm{mM} \mathrm{NaPO}$, $\mathrm{pH}$ 8.0. Fixative solution contained methanol : glacial acetic acid (3:1).

\subsection{Establishment of human limbal stem cell line $(\mathrm{Hu} / \mathrm{Li})$}

Removal of fibroblasts from stem cell culture. Stem cells of the limbus form a narrow zone between the cornea and the bulbar conjunctiva (Fig. 1). First we have cultivated the corneal disc under standard conditions. The observed spread of the corneal disc was accounted for by the fibroblasts that migrated from the corneal matrix, attached to surface of the flask, pulled and flattened the corneal disc (Video 1). To avoid the fibroblast supply by the cornea, the stem cell rich limbal collar was isolated and subjected to collagenase IV digestion and further growth of limbal cells. The viability of fibroblasts is known to last only for 5-6 days. After one week only the limbal stem cells were growing. The stem cell culture was tested by four tumor and two stem cell markers. Tumor and hematopoietic stem cell negative as well as cytokeratin 19 epidermic marker positive tests confirmed the limbal origin of our cell culture (Table 1).

Isolation of limbal stem cells. Detailed description of isolation was as follows. Corneal epithelial limbus was obtained from the enucleated eye of the cadaver of a 56-year-old female patient, whose eye was intact previously. We followed the European Community (EC) Tissues and Cells Directive 2004/23/EC on presumed consent practice for tissue collection. All examinations and sample collections were conducted according to the tenets of the Declaration of Helsinki and followed the guidelines of our Institutional Ethics Committee. 
The isolation procedure followed strict guidelines (Albert et al., 2012). The corneal disc was stored in Eusol-C storage liquid at $4{ }^{\circ} \mathrm{C}$. For medical transplantation the central corneal disc was used in full thickness. For in vitro experiments the remaining corneoscleral limbus was kept in Eusol-C corneal storage medium until further use. The outer surface of corneoscleral rim was disinfected with $70 \%$ ethanol to avoid bacterial infection, washed four times with betadine antiseptic solution and then with Dulbecco's Modified Eagle's Medium - F-12-Ham (DMEM-F12) containing 10\% FBS. For each phase of washing new sterile instruments were used. The tissue was then minced to $2 \times 2 \times 2 \mathrm{~mm}$ slices. Cornea pieces were placed in $5 \mathrm{ml}$ DMEM-F12 (+10\% FBS, + 1\% PSN) containing $800 \mathrm{U} / \mathrm{ml}$ collagenase IV and incubated at $37{ }^{\circ} \mathrm{C}$ for $2 \mathrm{~h}$. The resulting collagen-free endo-epithelial cell mixture was filtered through four layers of sterile gauze, washed, and suspended in DMEM-F12 supplemented with 10\% FBS and 1\% PSN. The commercially available penicillin-sterptomycin-neomycin (PSN) solution $(100 \%)$ is formulated to contain $100 \mathrm{x}$ concentrated 5,000 units/ml penicillin ( $5 \mathrm{mg} / \mathrm{ml}), 5 \mathrm{mg} / \mathrm{ml}$ streptomycin and $10 \mathrm{mg} / \mathrm{ml}$ neomycin in $0.9 \%$ sodium chloride solution.

Primary mechanisms of antibiotics. PSN are among the most widely used antimicrobial antibiotics in mammalian cultures. Penicillin is known to inhibit the cell wall synthesis of Gram positive bacteria causing their rapid cell death. At low concentrations streptomycin induces prokaryotic ribosomes to misread mRNA and as a broad-spectrum antibiotic inhibits the growth of both Gram-positive and Gram-negative bacteria. Neomycin inhibits translation by binding to the small subunit of prokaryotic ribosomes. Although, eukaryotic cells have also ribosomes, but they are structurally different, thus streptomycin and neomycin act selectively on bacteria. Chloramphenicol is a broad-spectrum antibiotic with bacteriostatic effect inhibiting the peptidyl transferase activity of the bacterial ribosome and preventing protein synthesis. Rifampicin inhibits bacterial DNA-dependent RNA synthesis by inhibiting bacterial DNA-dependent RNA polymerase. 
Antimicrobial antibiotics prevent bacterial growth, and cause only minor changes in the enzymatic activities of mammalian cells (Martinez-Liarte et al., 1995). Before the application of chloramphenicol or rifampicin in stem cell cultures we have tested the effect of 50x PSN (2x diluted) on limbal cell growth, and no inhibition was observed. Limbal cells grown in the presence of 100x diluted penicillin-sterptomycin-neomycin (PSN) in growth medium containing $50 \mu \mathrm{g} / \mathrm{ml}$ penicillin, $50 \mu \mathrm{g} / \mathrm{ml}$ streptomycin and $100 \mu \mathrm{g} / \mathrm{ml}$ neomycin excluded the harmful effect of PSN under our experimental conditions.

Limbal cell growth. Cells resuspended in DMEM-F12 containing 10\% FBS and 1\% PSN were incubated overnight at $37{ }^{\circ} \mathrm{C}$ in $5 \%$ carbon dioxide atmosphere, non-adherent cells were discarded and adherent cells cultured to develop into a monolayer cell culture. The primary limbal cells were further grown, and after 20 subculturing steps the limbal stem cell culture was established. Three weeks after culturing limbal cells were used for in vitro experiments. This time was also needed to scale up the cell culture for chromatin isolation and treatment of cells with antibiotics. Limbal stem cells were plated at 30-40\% confluency in glass bottom dishes (WillCo Wells BV, Amsterdam, hole diameter $30 \mathrm{~mm}$ ) and grown in the absence or in the presence of different concentrations of chloramphenicol $(0.5-1.0 \mathrm{mg} / \mathrm{ml})$ or rifampicin $(0.1-0.2 \mathrm{mg} / \mathrm{ml})$ in a carbon dioxide incubator at $37^{\circ} \mathrm{C}$ and $5 \% \mathrm{CO}_{2}$.

Characterization of limbal stem cells. Morphological considerations and the expression of various proteins were used to identify and characterize the limbal stem cell population. The small size $(\sim 10 \mu \mathrm{m}$ in diameter $)$ contributed to the isolation and identification of limbal stem cells. After 20 subcultures limbal epithelial stem cells were morphologically seen as small cells with a high nucleus-to-cytoplasm ratio with the cytoplasm lacking visible granular structures. These general morphological features have been supplemented with the expression of various proteins to identify and characterize the stem cell line of human limbal origin (Table 1). The positive expression for cytokeratin 19 of limbal basal cells was taken as an indicator of stem cell origin (Kasper et al., 1988), while the negative test with the CD34 
marker excluded the hematopoietic origin of stem cells. The human limbal stem cell line $(\mathrm{Hu} / \mathrm{Li})$ is freely available in our cell biology laboratory exclusively for in vitro experimental purposes.

\subsection{Long-term scanning microscopy and image analysis}

We have recently developed computer-based image analysis of long-term scanning (LTS) microscopy that allows visualization and analysis of mammalian and cell growth up to two weeks (Nagy et al., 2010; Banfalvi et al., 2012). Detailed description of the system and protocol for time-lapse scanning (TLS) is given (Nagy et al., 2014).

\subsection{Scratch model mimicking corneal epithelial growth}

The scratch wound assay mimics cell behaviour during wound healing in vitro in a confluent cell layer (Liang et al., 2007). This model referred to as scratch model mimics the regeneration of damaged corneal epithelium only when cell monolayer shrinkage and artifact formation are avoided. When a sterile $10 \mu \mathrm{l}$ automatic pipette tip with conical end was used to scratch the cellular monolayer, damaged cells started to shrink followed by the monolayer extension (Video 2). To avoid the smudging of cells the monolayer was scratched with the sharply cut metal tip of a sterile 20 gauge hypodermic needle (Videos 3-5). Control limbal cells in glass bottom dish were grown in DMEM-F12 + 10\% FBS $+1 \%$ PSN in carbon dioxide incubator at $37{ }^{\circ} \mathrm{C}$ at $5 \% \mathrm{CO}_{2}$ until confluency $(\sim 48 \mathrm{~h})$ was reached. The monolayer was scratched with the sterile 20 gauge hypodermic needle. Time-lapse video microscopy combined with image analysis turned out to be a convenient and reliable method of testing the regrowth of defect area in the absence and presence of antibiotics. Limbal cells in the presence of antibiotics were grown for the same period of time as the control population in the 
carbon dioxide incubator at $37{ }^{\circ} \mathrm{C}$ at $5 \% \mathrm{CO}_{2}$ and reached about $60-80 \%$ confluency, then scratched and further grown until the homogeneity of the culture was regained.

\subsection{Regrowth of damaged monolayer visualized by scanning electronmicroscopy (SEM)}

Three identical cultures grown on glass bottom dishes and damaged by scratching their monolayers were fixed at 0,3 and $6 \mathrm{~h}$, respectively for $30 \mathrm{~min}$ at $0{ }^{\circ} \mathrm{C}$ with $2.5 \%$ glutaraldehyde in PBS. After washing with the same buffer cells were fixed for a further 30 min at $0{ }^{\circ} \mathrm{C}$ with $2.5 \%$ osmium tetroxide in the same buffer. Cells were dehydrated stepwise, using increasing concentrations of ethanol in the rage of $50-100 \%$. Cells were coated with gold for viewing by a Hitachi S 4300 scanning electronmicroscope.

\subsection{Regrowth of damaged monolayer in the presence of antibiotics}

Five cell cultures, including control cells and two antibiotics of clinical importance were tested by the scratch model: i) Control cells grown in the absence of antibiotics, ii) chloramphenicol $(0.5 \mathrm{mg} / \mathrm{ml})$, iii) Chloramphenicol $(1.0 \mathrm{mg} / \mathrm{ml})$, iv) rifampicin $(0.1 \mathrm{mg} / \mathrm{ml})$, v) rifampicin $(0.2 \mathrm{mg} / \mathrm{ml})$. The size of the scratch and its regrowth were followed by timelapse microscopy until the scratched surface disappeared and confluency was regained. As the damaged areas varied from experiment to experiment, the area of defect was quantified from the photography by using a computer-assisted ImageJ processing program and was calculated as the percentage of residual epithelial defect at each time point. 


\subsection{Isolation of nuclei}

Trypsinization of adherent cells. Monolayer cells were washed twice with Phosphate Buffered Saline (PBS). After the removal of PBS a minimal volume (i.e. $0.9 \mathrm{ml}$ for a T25 flask) of $0.25 \% \mathrm{w} / \mathrm{v}$ trypsin solution (prewarmed to $37^{\circ} \mathrm{C}$ ) was added. Cells were sitting in the incubator for 1-10 min then the flask was checked under inverted microscope to make sure that the monolayer of cells was lifting off of the flask. The cell suspension was transferred to a sterile $15 \mathrm{ml}$ conical centrifuge tube. Cells were pelleted at $500 \mathrm{~g}$ for 5 minutes in the tabletop centrifuge. The supernatant was discarded carefully, so as not to disturb the cell pellet.

Determination of viable cell number. Cells were resuspended in $5 \mathrm{ml}$ PBS and $50 \mu \mathrm{l}$ cell suspension was given to $50 \mu 10.5 \%$ trypan blue dissolved in PBS. Viable cells that did not take up trypan blue were counted in a Bürker chamber. After cell number (cells/ml) was determined, $10^{6}$ cells were taken for osmotic swelling.

Reversible permeabilization. This method originally developed for the reversible permeabilization of lymphocytes isolated from the murine thymus (Banfalvi et al., 1984), was adapted to limbal cells. Cells were grown in DMEM-F12 containing T-25 flasks were washed with PBS and removed by tripsinization. Then $1 \mathrm{ml}$ of Hypotonic Buffer was added to $10^{6}$ lymbal cells in the presence of Dextran T-150 as a molecular coat to prevent cells from disruption. Permeabilization lasted for $1 \mathrm{~min}$ at $0^{\circ} \mathrm{C}$. For reversal of permeabilization, the hypotonic solution was replaced by DMEM-F12 medium containing $10 \%$ fetal bovine serum and $1 \% \mathrm{PSN}$, and the cells were incubated in a $\mathrm{CO}_{2}$ incubator at $37^{\circ} \mathrm{C}$ and $5 \% \mathrm{CO}_{2}$ for $3 \mathrm{~h}$ to prevent them from entering a new cell cycle (Banfalvi et al., 1984).

Osmotic cell swelling. Cells $\left(10^{6}\right)$ were washed twice with PBS and incubated at $37^{\circ} \mathrm{C}$ for 10 min in Swelling Buffer. Swelling was followed by centrifugation at $500 \mathrm{~g}$ for $5 \mathrm{~min}$. 
Isolation of nuclei. After swelling nuclei were isolated from the pellet of cells by the slow addition under constant stirring of $14 \mathrm{ml}$ Fixative Solution. Nuclei were then centrifuged at $500 \mathrm{x} \mathrm{g}$ for $5 \mathrm{~min}$ and washed twice in Fixative.

\subsection{Spreads of nuclear structures}

During preparation of nuclei for spreads of chromatin structures the method developed for metaphase chromosomes was used. Nuclei were centrifuged at $500 \mathrm{x} \mathrm{g}$ for $5 \mathrm{~min}$ and resuspended in $1 \mathrm{ml}$ Fixative. Nuclei were spread over glass slides dropwise from a height of approximately $30 \mathrm{~cm}$. Slides were air dried, stored at room temperature overnight, rinsed with PBS and dehydrated using increasing concentrations of ethanol (70, 90, 95 and 100\%).

\subsection{Visualization of chromatin structures}

Dehydrated slides containing chromatin structures were mounted in $35 \mu 1$ Antifade Medium under 24x50 mm coverslips. Blue fluorescence of DAPI was monitored by fluorescence microscopy (Nikon Eclipse E800 Nikon Corporation, Tokyo).

\section{Results}

\subsection{Regeneration of limbal cell growth}

Cell growth in the presence of antibiotics aimed to prove the inverse relationship between cell growth and antibiotic concentration. The growth rate was determined by the number of divisions seen as round mitotic cells in the time-lapse scanning microscopy (Nagy et al., 2013). Five identical limbal cell cultures were replated, each of them was started at $10^{6}$ cells $/ \mathrm{ml}$, one in the absence and four in the presence of 0.5 and $1.0 \mathrm{mg} / \mathrm{ml}$ chloramphenicol, 0.1 and $0.2 \mathrm{mg} / \mathrm{ml}$ rifampicin, respectively. The growth of the control cell culture after $24 \mathrm{~h}$ 
incubation showed $100 \%$ confluency. The growth rate in the presence of 0.5 and $1.0 \mathrm{mg} / \mathrm{ml}$ chloramphenicol was reduced to $\sim 80-70 \%$, and by 0.1 and $0.2 \mathrm{mg} / \mathrm{ml}$ rifampicin to $\sim 70-$ $60 \%$, relative to the $100 \%$ of the $24 \mathrm{~h}$ control population of limbal cells.

The in vitro regeneration of monolayer was followed by time-lapse microscopy after scratching the surface of the confluent monolayer of the limbal cell culture. In the control experiment the detachment of injured cells at the edges of the damage was followed by an initial steep increase in regeneration, corresponding to a logarithmic growth rate curve. The regeneration profile of control cells can be subdivided into four subphases (Fig. 2A/a): i) an initial steep increase corresponding to the reattachment of the burst open rim of the monolayer, lasting for about $3 \mathrm{~h}$, ii) exponential phase of regrowth of scratched surface between 3 and $7 \mathrm{~h}$, iii) transition from $\log$ phase to stationary phase between 7 and $8 \mathrm{~h}$ and iv) stationary phase between 8 and 24 h. The vigorous cell movement with initial large oscillations shows the intensity of cell growth that came to a stand-still after $\sim 8 \mathrm{~h}$ (Fig. $2 \mathrm{~A} / \mathrm{b}$ ). The trendline of regeneration can be defined by a logarithmic graph and equation presented in Fig. 2D.

\subsection{Antibiotics affecting the regeneration of limbal cell growth}

The regeneration potential of damaged monolayer upon treatment with $0.5 \mathrm{mg} / \mathrm{ml}$ chloramphenicol was followed by time-lapse imaging for $24 \mathrm{~h}$. The lagging period of cell growth before exponential growth lasted for $\sim 7 \mathrm{~h}$ (Fig. 2B/a). The trendline of the graph (Fig. 2B/a) was described by the equation given in Fig. 2D.

The in vitro regeneration of $0.1 \mathrm{mg} / \mathrm{ml}$ rifampicin treated cells was visualized in the same manner by time-lapse microscopy after scratching the surface of the confluent monolayer of limbal cells (Fig. 2C/a). The profile of monolayer regeneration shows a relatively fast reattachment of damaged monolayer followed by delayed cell growth indicated by the 
reduced rise of the curve and did not reach the stationary phase during the $24 \mathrm{~h}$ observation period. The trendline of graph of Fig. 2C/a was expressed by the equation given in Fig. 2D.

In the panels of Fig. $2 \mathrm{~A} / \mathrm{b}, 2 \mathrm{~B} / \mathrm{b}$ and $2 \mathrm{C} / \mathrm{b}$ positive upward oscillations from the mean values indicate surface extensions that may arise from: i) reattachment of scratched monolayer parts, ii) cellular immigration, iii) cellular extension, iv) cell proliferation. Negative downward oscillations of surface reduction reflect: i) damaged cells, ii) apoptosis, iii) transient, or permanent cellular shrinkage, iv) transient surface reduction due to mitotic detachment.

\subsection{In vitro regeneration of monolayer visualized by time-lapse microscopy}

The in vitro regeneration of damaged monolayer of limbal cell culture was visualized by time-lapse microscopy after scratching the surface of the confluent monolayer. In the control experiment the lagging period of cell growth $(\sim 3 \mathrm{~h})$ was accounted for by the reattachment of cells at the edges of the damaged monolayer and was followed by a steep increase in cell growth. That detached cells did not die is indicated by the rapid repopulation of the scratched surface reaching high confluency within $5 \mathrm{~h}$ (Fig. 3 top left panels).

Time-lapse microscopy demonstrated that complete regrowth after $0.5 \mathrm{mg} / \mathrm{ml}$ chloramphenicol treatment of limbal cell culture took about $700 \mathrm{~min}(11 \mathrm{~h}$ and $40 \mathrm{~min})$ confirming the inhibitory effect of chloramphenicol on limbal cell regeneration (Fig. 3 middle left panels). The temporal shift between the beginning of regrowth and reattachment pointed to a significant loss of cells, seen in the time-lapse microscopy as residual bodies of apoptosis (Fig. 3 middle left panels).

The scratch model proved to be useful to reveal a drastic reduction of limbal growth and delayed regeneration of the endothelial monolayer exerted by the presence of $0.1 \mathrm{mg} / \mathrm{ml}$ 
rifampicin. Fig.3 bottom left panels show how the empty surface caused by the scratch was regrown. Complete regeneration took more than $900 \mathrm{~min}(15 \mathrm{~h})$ (Fig. 3 bottom left panels).

The regeneration of damaged monolayer was confirmed by scanning electronmicroscopy. Three identical monolayer limbal cell cultures of about $80 \%$ confluency were damaged by scratching their surfaces. The top right panel of Fig. 3 shows an initial $\sim 450 \mu$ m wide empty belt devoid of cells with residual bodies in the middle of the streak. After $3 \mathrm{~h}$ of regeneration the empty band narrowed to less than $100 \mu \mathrm{m}$ (middle right panel of Fig. 3) and after $6 \mathrm{~h}$ to about $20 \mu \mathrm{m}$ (bottom right panel of Fig. 3).

\subsection{Intermediates of chromatin condensation in nuclei of untreated stem cells}

Reversible permeabilization of limbal cells was used to open the nucleus and to visualize large scale chromatin changes. Similarly to other mammalian (CHO, Indian muntjac, murine preB and human K562 erythroleukemia) cells (Banfalvi et al., 2006), it was expected that intermediates of chromosome condensation in stem cells could be traced and would correspond to those seen in tumor cells. Chromatin structures presented in Fig. 4 have been arranged in numbered rows and lettered columns to distinguish among individual panels. Intermediates of chromatin condensation in healthy limbal stem cells included round nuclei containing veil-like chromatin in early S phase (Fig. 4 top A/1-6), polarization of nuclei (Fig. 4 B/1-6), initial supercoiling and elongation of chromatin veil (Fig. 4 C/1-6), condensed chromatin veil subdivided into five major chromatin clusters (Fig. 4 D1-6), supercoiled chromatin ribbon (Fig. 4 E/1-6), ribbons turning to earliest visible interphase chromosomes referred to as chromatin bodies (Fig. 4 F/1-G/6), chromatin bodies turning to spiral shaped, bent $\mathrm{u}$ and $\mathrm{v}$ shaped prechromosomes and metaphase chromosomes (Fig. 4 bottom H/1-6). Intermediates of chromation condensation of Fig. 4 demonstrate how these regular forms 
differ from those that have been isolated from limbal stem cells, but subjected to antibiotic treatment.

\subsection{Chromatin changes induced by antibiotics}

Lower than $0.1 \mathrm{mg} / \mathrm{ml}$ chloramphenicol concentrations did not cause significant changes in chromatin structure relative to the control. Minor chromatin changes were observed after $0.1 \mathrm{mg} / \mathrm{ml}$ chloramphenicol treatment (not shown). Upon treatment with $0.5 \mathrm{mg} / \mathrm{ml}$ chloramphenical local polarization of chromatin and the opening of nucleus were typical chromatin changes that could be seen (Fig. 5 left panels). The swelling and opening of nuclei often took place in such a manner that it revealed the two ends of the continuous chromatin structure. In rare occasions incompletely folded chromosomal forms were observed that did not reach the compaction of the metaphase (Fig. 5X, left panel).

In the presence of higher chloramphenicol $(1 \mathrm{mg} / \mathrm{ml})$ concentration the chromatin maintained its fibrillary form, did not turn to chromatin ribbon and due to the stickiness of the chromatin nuclei were not disrupted but moderately enlarged. Characteristic genotoxic changes exerted by $1 \mathrm{mg} / \mathrm{ml}$ chloramphenicol are seen in Fig. 5 right panels.

When cell were grown in the presence of lower concentration of rifampicin $(0.1 \mathrm{mg} / \mathrm{ml})$ initial chromatin folding took place resulting in characteristic holes in nuclei (Fig. 6 left panels). That further chromatin condensation did not occur could be accounted for by the stickiness of the chromatin fibers. At higher rifampicin concentration $(0.2 \mathrm{mg} / \mathrm{ml})$ chromatin toxicity manifested primarily as supercoiled chromatin ribbons without the appearance of higher order of chromatin folding (Fig. 6 right panels). 


\section{Discussion}

In the reconstitution of non-penetrating damages of the cornea the human amniotic membrane has been a useful matrix to expand limbal stem cells in vitro before the transplantation of autologous limbal epithelial cells to the ocular surface (Tsai et al., 2000). Alternatively, limbal stem-cell therapy and long-term corneal regeneration proved to be useful for the treatment of the damaged human cornea (Rama et al., 2010). The major advantage of limbal cell therapy is that these cells can be grown in unlimited quantity without somewhat laborious growth on biomembranes.

The reason why corneal regeneration after ocular-surface injury and antibiotic treatment can last up to 2-3 months was not known. The long treatment understandably necessitated the prevention of bacterial infections by broad-spectrum antibiotics, but harbored the further risk of slowing down the healing process, beside other ophthalmic side effects. The in vivo effectiveness of topical antibiotics may depend on their ability to associate with epithelial cells to provide continued protection (Wingard et al., 2011). However, topical treatment of antibiotics may also damage limbal stem cells. High-dose topical mitomycin C turned out to be associated with a relatively high incidence of limbal stem cell deficiency (Lichtinger et al., 2010). In most instances broad-spectrum antibiotics are preferred as eye drops since they are more practical than ointments and vision is not blurred with eyedrops. Under experimental conditions ocular-suface injuries of albino rabbits were treated with $0.5 \%$ levofloxacin eyedrops and $1 \mathrm{mg} / \mathrm{kg}$ intramuscular gentamicin (Nakamura et al., 2003). For clinical application chloramphenicol and gentamicin are among the broad spectrum antibiotics that are preferentially used. Chloromycetin (Chloramphenicol) Ophthalmic Ointment USP, 1\% (10 $\mathrm{mg} / \mathrm{g}$ ) is indicated for the treatment of ocular infections involving the conjunctiva and/or cornea caused by several chloramphenicol-susceptible organisms. 
The in vitro effect of antibiotics on limbal regeneration has not been tested. Although, a glass culture system cannot be considered identical to an in vivo situation, it can be useful to mimic limbal growth. Our experiments may serve as a basis for the in vivo regeneration of limbal cells in the presence of antibiotics. The comparison of the two antibiotics tested show that rifampicin has more severe side effects on limbal cells than chloramphenicol. Thus we have lowered the concentrations of rifampicin $(0.1-0.2 \mathrm{mg} / \mathrm{ml})$ relative to chloramphenicol $(0.5-1.0 \mathrm{mg} / \mathrm{ml})$. For the regeneration of limbal cell monolayer the scartch model proved to be useful to test the regrowth of the destroyed continuity of limbal monolayer by time-lapse microscopy. Regrowth of monolayer was confirmed by scanning electronmicrocopy. As a corollary of the reduced limbal cell growth by antibiotics, significant differences were observed in the duration of regeneration of control, untreated limbal cells taking about $5 \mathrm{~h}$, versus the reconstitution in the presence of $0.5 \mathrm{mg} / \mathrm{ml}$ chloramphenicol $(\sim 12 \mathrm{~h})$ or $0.1 \mathrm{mg} / \mathrm{ml}$ rifampicin $(\sim 15 \mathrm{~h})$.

Our results show that the chromosome condensation of natural limbal stem cells follows the same common pattern as that of other mammalian tumor cells (Banfalvi et al., 2006). Chromatin condensation in limbal cells subjected to antibiotic treatment confirmed the damaging effects of antibiotics. Chloramphenicol used at lower $(0.5 \mathrm{mg} / \mathrm{ml})$ concentration caused the opening of nuclei during chromatin condensation, higher concentration $(1 \mathrm{mg} / \mathrm{ml})$ prevented the transition of fibrillar to ribboned chromatin. This inhibition resembled damages caused by ultraviolet-B irradiation where reversible chromatin changes were seen as a fine fibrillary network covering the inner, more condensed structures (Ujvarosi et al., 2007). Corresponding to this similarity we regard these chromatin changes less detrimental than those generated by rifampicin. Chromatin damages of rifampicin at lower $(0.1 \mathrm{mg} / \mathrm{ml})$ concentration are relatively uniform and seem to block the cell cycle at the ribboned stage of chromatin condensation in conformity with the results of the time-lapse microscopy where a $10 \mathrm{~h}$ delay in cell regrowth was registered with a potentially synchronizing effect. At higher 
concentration of rifampicin $(0.2 \mathrm{mg} / \mathrm{ml})$ the various shapes of nuclei and condensation forms of chromatin indicated more severely damaged limbal cells.

The therapeutic use of rifampicin is of particular concern already at $0.1 \mathrm{mg} / \mathrm{ml}$ concentration, as it significantly slows down the regeneration process and causes nuclear damages confirmed by the distorted chromatin structures. Based on these in vitro experiments one can predict that during the medical applications rifampicin also exerts its harmful effects, that should be minimized by keeping its concentration at the lowest bactericidal level. The therapeutic concentration for the external clinical use of chloramphenicol is probably less than $0.5 \mathrm{mg} / \mathrm{ml}$, and the recommended rifampicin concentration less than $0.1 \mathrm{mg} / \mathrm{ml}$.

\section{Conclusion}

We have established an in vitro cell culture system that may resemble, but cannot be considered identical to in vivo situations, consequently it would be early to regard our system as a stem cell model for corneal epithelial wound healing. In conformity with clinical observations the antibiotics (chloramphenicol, rifampicin) tested, delay the growth of limbal stem cells. Genotoxicity specific differences in chromatin toxicity described earlier in this journal (Banfalvi et al., 2012) holds true of antibiotics as well. We have found earlier in different tumor cell lines similar chromatin structures during interphase that followed the same pattern of chromosome condensation (Banfalvi et al., 2006). In this paper we confirm the notion that naturally occuring stem cells contain the same intermediates and obey the general rules of chromatin condensation.

Conflict of interest The authors declare no conflict of interest. The research was not presented at a conference. 


\section{Acknowledgements}

This work was sponsored by TAMOP 4.2.4. A/2-11-1-2012-0001 grant to GN and TAMOP4.2.2/B-10/1-2010-0024 grant to AK-B.

\section{Appendix A. Supplementary data}

Supplementary data associated with this article can be found, in the online version at http:dx.doi.org/.....

\section{References}

Ahmad, S., 2012. Concise review: limbal stem cell deficiency, dysfunction, and distress. Stem Cells Translational Medicine 1, 110-115.

Albert, R,, Veréb, Z., Csomós, K., Moe, M.C., Johnsen, E.O., Olstad, O.K., Nicolaissen, B., Rajnavölgyi, E., Fésüs, L., Berta, A., Petrovski, G., 2012. Cultivation and characterization of cornea limbal epithelial stem cells on lens capsule in animal materialfree medium. PLoS One 7, e47187.

Banfalvi, G., Nagy, G., Gacsi, M., Roszer, T., Basnakian, A.G., 2006. Common pathway of chromosome condensation in mammalian cells. DNA and Cell Biology 25, 295-301.

Banfalvi, G., Sarvari, A., Nagy, G., 2012. Chromatin changes induced by $\mathrm{Pb}$ and $\mathrm{Cd}$ in human cells. Toxicology In Vitro 26, 1064-1071.

Banfalvi, G., Sooki-Toth, A., Sarkar, N., Csuzi, S., Antoni, F., 1984. Nascent DNA chains synthesized in recersibly permeable cells of mouse thymocytes. European Journal of Biochemistry 139, 553-559. 
Baylis, O., Figueiredo F., Henein, C., Lako, M., Ahmad, S., 2011. 13 years of cultured limbal epithelial cell therapy: A review of the outcomes. Journal of Cell Biochemistry 112, 993-1002.

Becker, Y., 1972. Rifampicin an anti-trachoma antibiotic. Israel Journal of Medical Sciences 8, 1110-1113.

Becker, Y., Asher, Y., Himmel, N., Zakay-Rones, Z., 1970. Anti-trachoma activity of rifampicin and rifampicin SV derivatives. Nature 225, 454-455.

Dua, H.S., Azuara-Blanco, A.. 2000. Autologous limbal transplantation in patients with unilateral corneal stem cell deficiency. British Journal of Ophthalmology 84, 273-278.

Dua H.S., Miri, A.,Said, D.G., 2010. Contemporary limbal stem cell transplantation - a review. Clinical and Experimental Ophthalmology 38, 104-117.

Fraunfelder, F.T., Meyer, S.M., 1982. Drug-induced ocular side-effects and drug interactions. 2nd ed Lea and Febiger, Philadelphia

Frucht-Pery, J.,Siganos, C.S., Solomon, A., Scheman, L., Brautbar, C., Zauberman, H., 1988. Limbal cell autograft transplantation for severe ocular surface disorders. Graefe's Archive of Clinical and Experimental Ophthalmology 236, 582-587.

Kasper, M., Mol,1 R., Stosiek, P., Karsten, U., 1988. Patterns of cytokeratin and vimentin expression in the human eye. Histochemistry 89, 369-377.

Kheirkhah, A., Karimian, F., 2010. A Case of Autologous Cultivated Limbal Stem Cell Transplantation. Journal of Ophthalmic and Vision Research 5, 130-135.

Kinoshita, S., Friend, J., Thoft, R.A., 1981. Sex chromatin of donor corneal epithelium in rabbits. Investigative Ophthalmology and Vision Science 21, 434-441.

Kruse, F.E., Tseng, S.C., 1993. Serum differentially modulates the clonal growth and differentiation of cultured limbal and corneal epithelium. Investigative Ophthalmology and Vision Science 34, 2976-2989. 
Liang, C.C., Park, A.Y., Guan, J.L., 2007. In vitro scratch assay: a convenient and inexpensive method for analysis of cell migration in vitro. Nature Protocols 2, 329-333.

Lichtinger, A., Pe'er, J., Frucht-Pery, J., Solomon, A., 2010. Limbal stem cell deficiency after topical mitomycin $\mathrm{C}$ therapy for primary acquired melanosis with atypia. Ophthalmology $117,431-437$.

Majo, F., Rochat, A., Nicolas, M., Jaoude, G.A., Barrandon, Y., 2008. Oligopotent stem cells are distributed throughout the mammalian ocular surface. Nature 456, 250-254.

Martínez-Liarte, J.H., Solano, F., Lozano, J.A. 1995. Effect of penicillin-streptomycin and other antibiotics on melanogenic parameters in cultured B16/F10 melanoma cells. Pigment Cell Res.8, 83-88.

Nagy, G., Hennig, G.W., Petrenyi, K., Kovacs, L., Pocsi, I., Dombradi, V., Banfalvi, G., 2014. Time-lapse video microscopy and image analysis of adherence and growth patterns of Candida albicans strains. Applied Microbiology and Biotechnology doi: 10.1007/s00253-014-5696-5

Nagy, G., Pinter, G., Kohut, G., Adam, A.L., Trencsenyi, G., Hornok, L., Banfalvi, G., 2010. Time-lapse analysis of cell death in mammalian and fungal cells. DNA and Cell Biology $29,249-259$.

Nakamura, T., Endo, K., Cooper, L.J., Fullwood, N.J., Tanifuji, N., Tsuzuki, M., Koizumi, N., Inatomi, T., Sano, Y., Kinoshita, S., 2003. The successful culture and autologous transplantation of rabbit oral mucosal epithelial cells on amniotic membrane. Investigative Ophthalmology and Visual Science 44, 106-116.

Rama, P., Matuska, S., Paganoni, G., Spinelli, A., De Luca, M., Pellegrini, G., 2010- Limbal stem-cell therapy and long-term corneal regeneration. New England Journal of Medicine $363,147-155$.

Romano, A.C., Espana, E.M., Yoo, S.H,, Budak, M.T,, Wolosin, J.M,, Tseng, S.C., 2003. Different cell sizes in human limbal and central corneal basal epithelia measured by 
confocal microscopy and flow cytometry. Investigative Ophthalmology and Visual Science 44, 5125-5129.

Secker, G.A,, Daniels, J.T., 2009. Limbal epithelial stem cells of the cornea. In: Watt, F., Gage, F. (Eds), Stem book [Internet]. The Stem Research Community. http://www.stembook.org

Shortt, A.J,, Secker, G.A,, Notara, M.D., Limb, G.A., Khaw, P.T., Tuft, S.J., Daniels, J.T., 2007- Transplantation of ex vivo cultured limbal epithelial stem cells: a review of techniques and clinical results. Survey of Ophthalmology 52, 483-502.

Sun, T.T., Tseng, S.C., Lavker, R.M., 2010. Location of corneal epithelial stem cells. Nature 463, E10-E11.

Tomiyama, T., Shoji, A., Kataoka, K., Suwa, Y., Asano, S., Kaneko, H., Endo, N., 1996. Inhibition of amyloid $\beta$ protein aggregation and neurotoxicity by rifampicin. Its possible function as a hydroxyl radical scavenger. Journal of Biological Chemistry 271, 6839_ 6844.

Tsai, R.J., Li, L., Chen, J., 2000. Reconstruction of damaged corneas by transplantation of autologous limbal epithelial cells. New England Journal of Medicine 343, 86-93.

Tseng, S.C., 1989. Concept and application of limbal stem cells. Eye (Lond) 3, 141-157.

Ujvarosi, K., Hunyadi, J., Nagy, G., Pocsi, I., Banfalvi, G., 2007. Preapoptotic chromatin changes induced by ultraviolet B irradiation in human erythroleukemia K563 cells. Apoptosis 12, 2089-2099.

Wingard, J.B., Romanowski, E.G., Kowalski, R.P., Mah, F.S., Ling, Y., Bilonick, R.A., Shanks, R.M., 2011. A novel cell-associated protection assay demonstrates the ability of certain antibiotics to protect ocular surface cell lines from subsequent clinical Staphylococcus aureus challenge. Antimicrobial Agents and Chemotherapy 55, 37883794. 


\section{Figures}

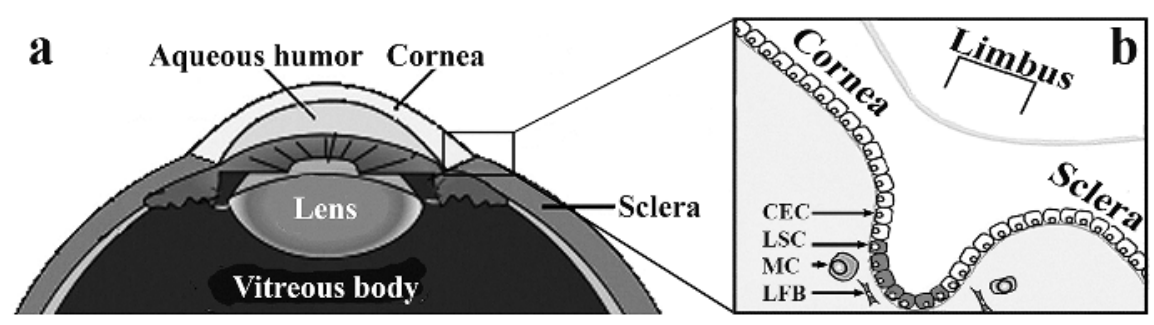

Figure 1. Schematic view of isolation of limbal cells. a) Limbal part of the human eye (boxed). b) Magnified view of limbus. $\mathrm{CEC}=$ corneal epithelial cell, $\mathrm{LSC}=$ limbal stem cell, $\mathrm{MC}=$ melanocyte LFB = limbal fibroblast. 

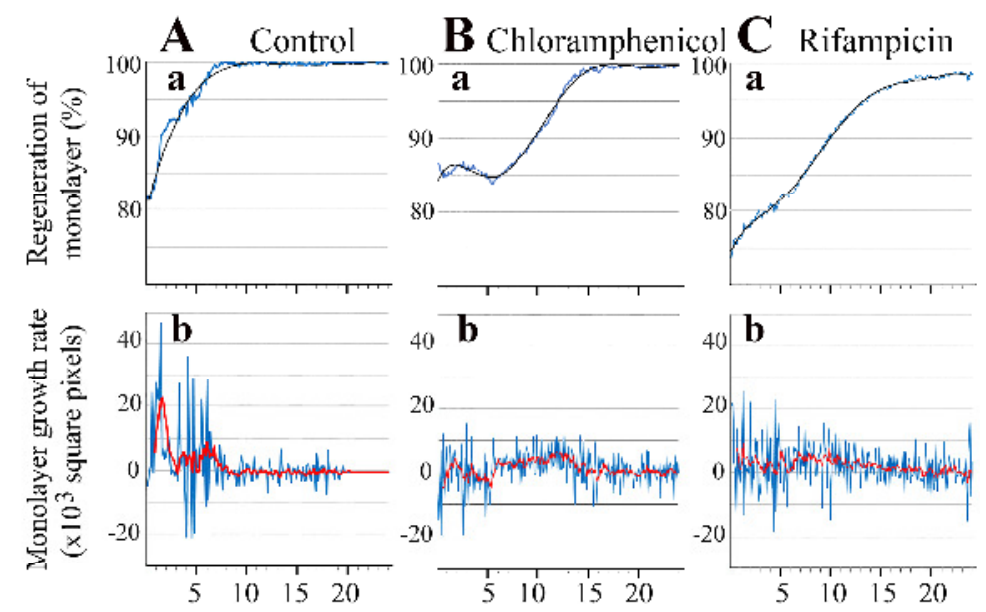

D

Time of regeneration (h)

\begin{tabular}{|c|c|c|}
\hline Graph & Trendline & Equation/Description \\
\hline $\mathrm{A} / \mathrm{a}$ & $\begin{array}{c}\text { Polynomial, Order } 4, \\
\mathrm{R}^{2}=0.9782\end{array}$ & $\mathrm{y}=-1 \mathrm{E}-0.7 \mathrm{x}^{4}+6 \mathrm{E}-05 \mathrm{x}^{3}-0.0098 \mathrm{x}^{2}+0.7251 \mathrm{x}+80.654$ \\
\hline $\mathrm{A} / \mathrm{b}$ & $\begin{array}{c}\text { Moving average, } \\
\text { period:6 }\end{array}$ & 30 minutes moving average \\
\hline $\mathrm{B} / \mathrm{a}$ & $\begin{array}{c}\text { Polynomial, Order 6, } \\
\mathrm{R}^{2}=0.9946\end{array}$ & $\mathrm{y}=-1 \mathrm{E}-11 \mathrm{x}^{6}+9 \mathrm{E}-0.9 \mathrm{x}^{5}-3 \mathrm{E}-06 \mathrm{x}^{4}+0.0003 \mathrm{x}^{3}-0.0189 \mathrm{x}^{2}+$ \\
$0.377 \mathrm{x}+84.08$
\end{tabular}

Figure 2. Regeneration of damaged monolayer surface in the absence and presence of ophthalmic antibiotics. A. Control scratch model to mimic the regeneration of monolayer. a) Black regeneration curve plotted as a function of time. b) Oscillations of growth rate indicating cellular surface motion changes within 5 min periods. B. Regeneration of monolayer after treatment with $0.5 \mathrm{mg} / \mathrm{ml}$ chloramphenicol. a) Regeneration of monolayer as a function of time (black curve). b) Growth rate indicated by the amplitudes of cellular growth/shrinkage within 5 minutes. C. Regeneration of scratched monolayer upon treatment with $0.1 \mathrm{mg} / \mathrm{ml}$ rifampicin. a) Regeneration followed by timelapse imaging for $24 \mathrm{~h}$ (black curve). b) Monolayer growth/shrinkage amplitudes. Blue graphs in upper panels $(\mathrm{A} / \mathrm{a}, \mathrm{B} / \mathrm{a}, \mathrm{C} / \mathrm{a})$ show the percentages of regeneration of damaged monolayers. Black graphs are characteristic trendlines that have been expressed by equations. Blue colored positive and negative oscillations of lower panels $(\mathrm{A} / \mathrm{b}, \mathrm{B} / \mathrm{b}, \mathrm{C} / \mathrm{b})$ represent monolayer surface extensions and reductions within two consecutive frames at 5 minutes time resolution. Red curves indicate the 30 minutes moving average of momentary surface changes at 5 minutes time resolution in 6 period averaging. D. Equations of graphs: A/a, B/a, C/a and trendlines: A/b, B/b, C/b. 

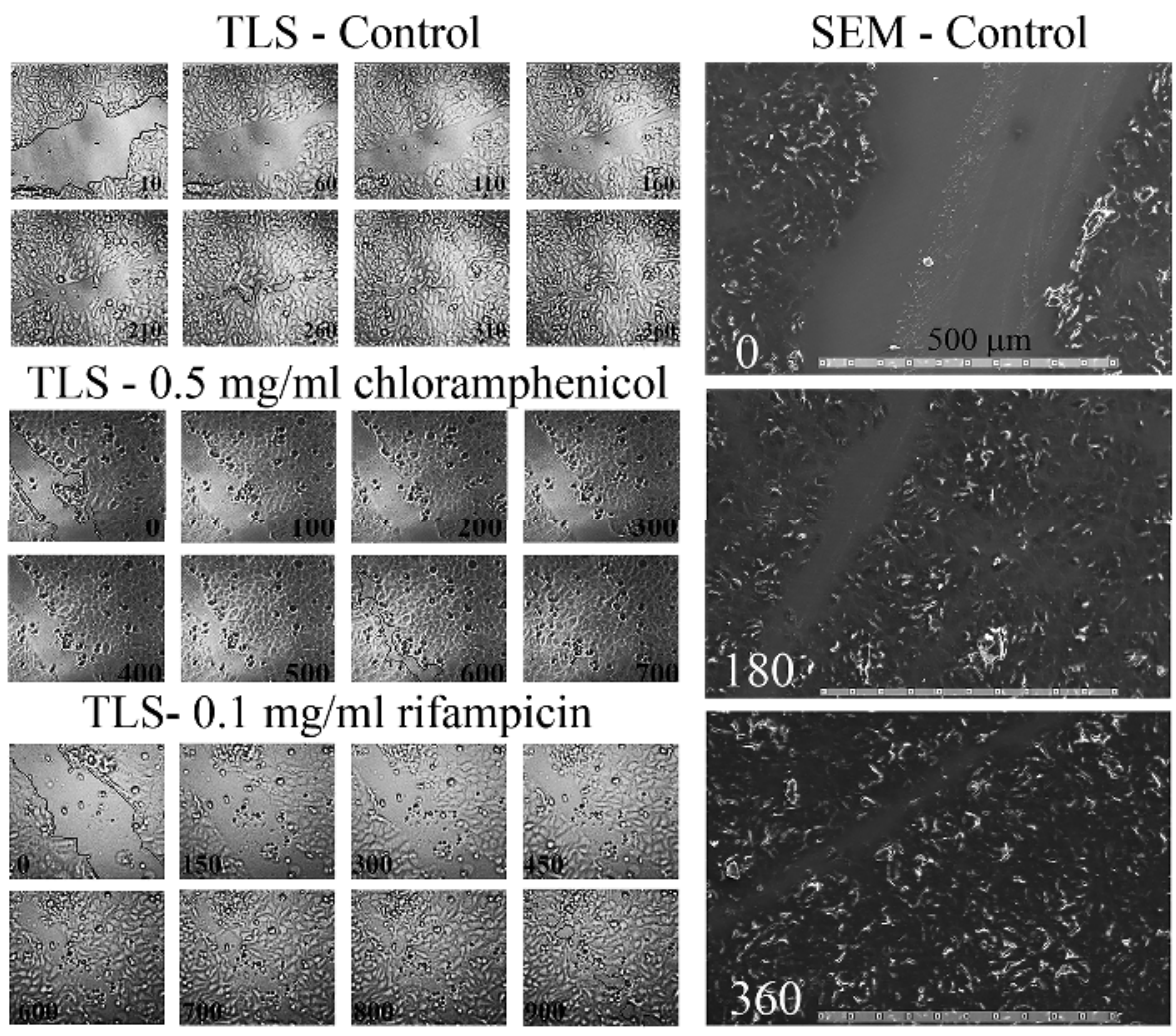

Figure 3. Monitoring regeneration of monolayer in scratch model by long term scanning and scanning electronmicroscopy. Limbal stem cell culture was grown until confluency of monolayer was reached (up to $48 \mathrm{~h}$ in a glass bottom dishes). The monolayer was scratched with a sterile 20 gauge hypodermic needle, resulting in a $\sim 40 \%$ loss of confluency in the visual field and then subjected to time-lapse microscopy. Upper left panels: Control cell growth followed by time-lapse videomicroscopy up to the regeneration of the disrupted area. The empty surface generated by the scratch is shown by the black ink from the beginning $(10 \mathrm{~min})$ of time-lapse imaging, to the complete regeneration $(310 \mathrm{~min})$. Middle left panels: Limbal cell culture was grown in the presence of $0.5 \mathrm{mg} / \mathrm{ml}$ chloramphenicol in a glass bottom dish. After reaching confluency the surface of the disc was sratched with a sterile 20 gauge needle. Regeneration of cell growth was traced by time-lapse videomicroscopy until the disrupted area was healed (700 min). Bottom left panels: Scratch model of monolayer healing affected by rifampicin and visualized by time-lapse videomicroscopy. Limbal stem cells were grown in the presence of $0.1 \mathrm{mg} / \mathrm{ml}$ rifampicin until confluency was attained. The monolayer was scratched with a sterile needle. Repopulation of monolayer was followed by time-lapse microscopy for $15 \mathrm{~h}$. Black numbers at the bottom of each frame show the time of photography in min. Videomicroscopic 
presentations of $\mathrm{A}, \mathrm{B}$ and $\mathrm{C}$ are provided in the attachment as videos \# 3, 4 and 5, respectively. Right panels: Scanning electronmicroscopy of monolayer regeneration. Electronmicroscopy was performed as described in the Methods. Upper panel: Monolayer of limbal stem cells after scratching. Middle panel: Monolayer regeneration $3 \mathrm{~h}$ after damage. Lower panel: Monolayer regeneration $6 \mathrm{~h}$ after damage. Bars, $500 \mu \mathrm{m}$ each. 


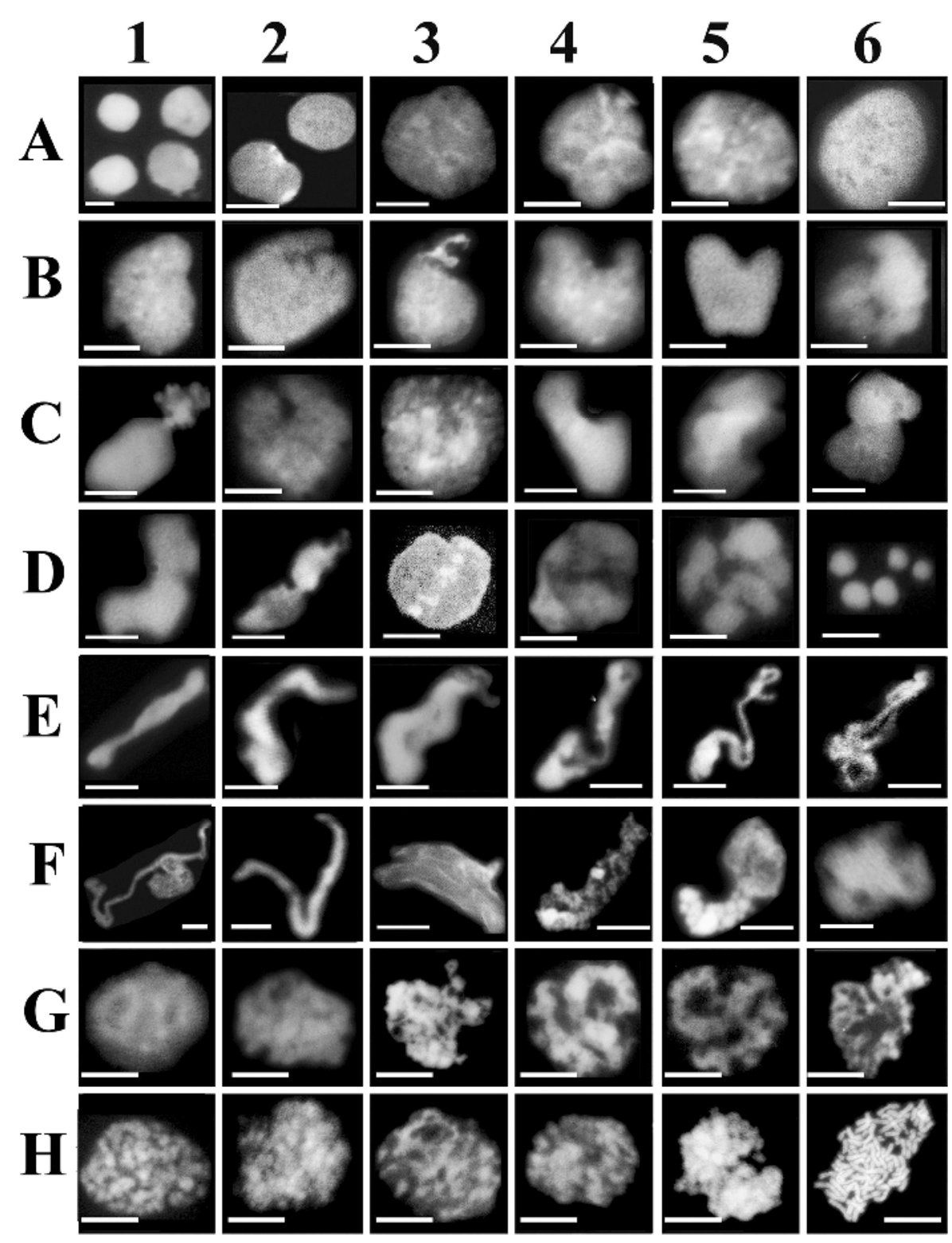

Figure 4. Intermediates of chromatin condensation of control limbal cells. Cells were grown, harvested, reversibly permeabilized and subjected to chromatin isolation and fluorescent microscopy as described in the Methods. Transitory stages of condensing chromosomes from chromatin veil (A1-C6), to chromatin ribbon (D1-F6), to chromatin bodies (early visible chromosomes) (G1-H3) and metaphase chromosomes (G4-G6). Bars, $5 \mu \mathrm{m}$ each. 


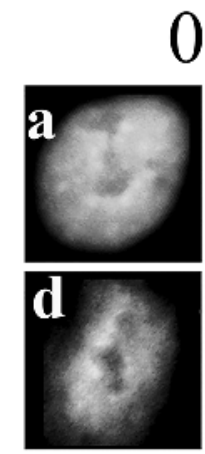

$0.5 \mathrm{mg} / \mathrm{ml}$
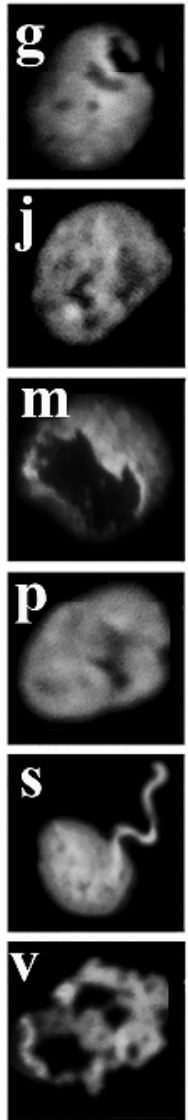
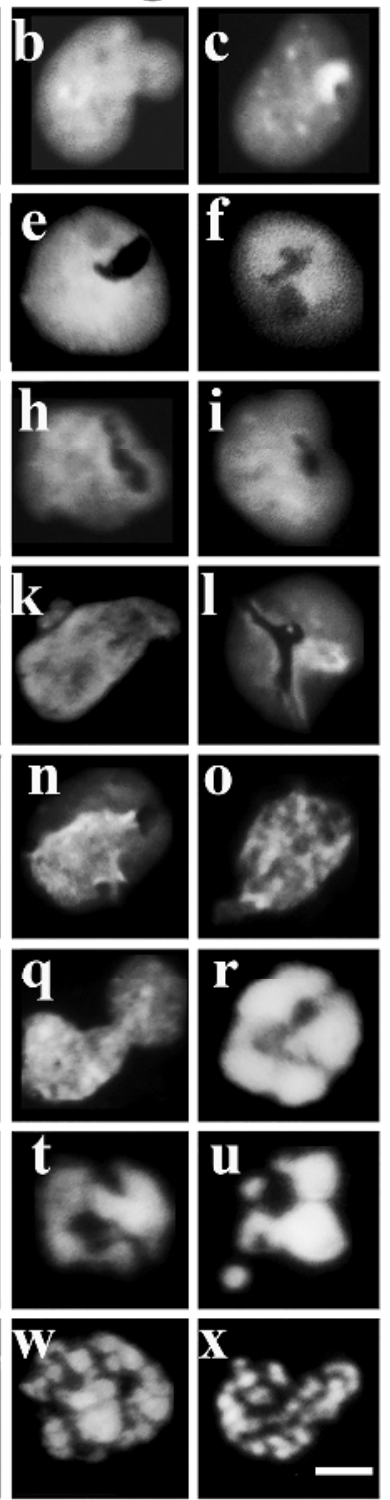

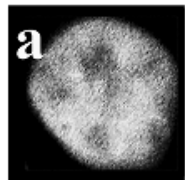

$1.0 \mathrm{mg} / \mathrm{ml}$
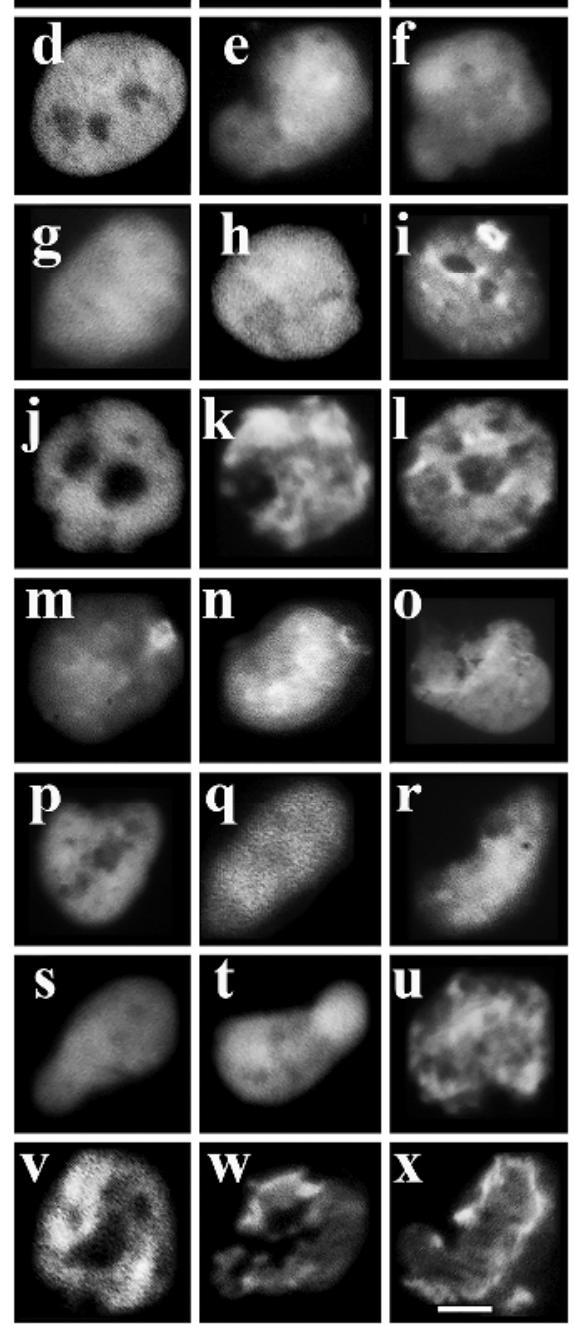

Figure 5. Chromatin changes in nuclei of limbal cells induced by chloramphenicol treatment. Limbal cells were grown in the presence of either $0.5 \mu \mathrm{g} / \mathrm{ml}$ chloramphenicol (left panels) or in the presence of $1.0 \mathrm{mg} / \mathrm{ml}$ chloramphenicol (right panels) harvested, reversibly permeabilized and subjected to chromatin isolation as described in the Methods. Characteristic opening of nuclei at lower concentration (left panels). Stickiness and enlargement of nuclei at higher chloramphenicol concentration (right panels). Bar, $5 \mu \mathrm{m}$ for each panel. 


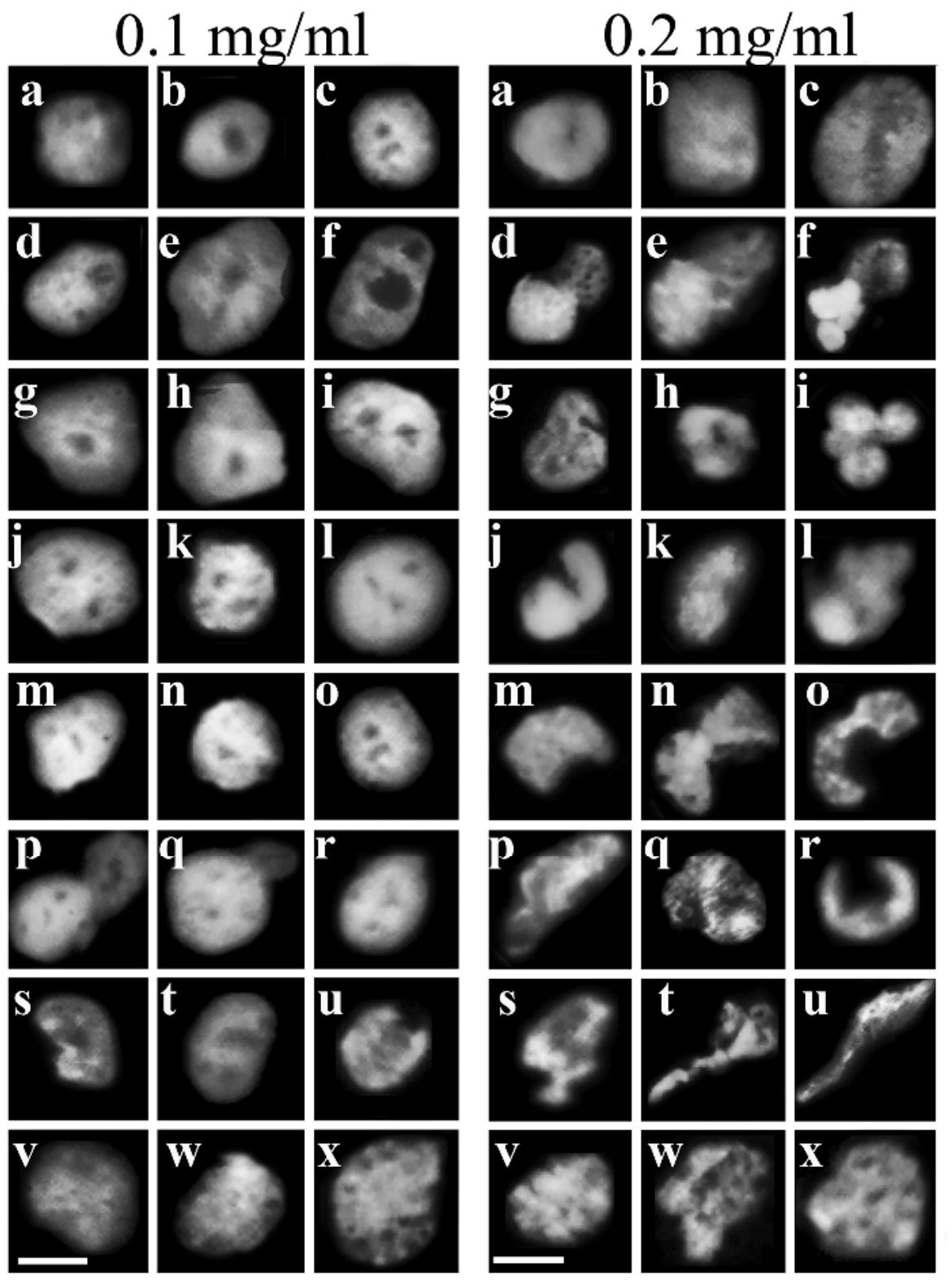

Figure 6. Effect of rifampicin on chromatin structure of limbal cells. Cells were grown in the presence of $0.1 \mathrm{mg} / \mathrm{ml}$ (left panels) or $0.2 \mathrm{mg} / \mathrm{ml}$ rifampicin (right panels). Growth conditions, isolation of chromatin structures and fluorescent microscopy are described in the Methods. Characteristic wholes in nuclei at lower concentration (left panels), elongated chromatin and rejection of fibrillary chromatin at higher concentration (right panels). Bars, $5 \mu \mathrm{m}$ each. 
Table 1

Cytogenetic characterization of $\mathrm{Hu} / \mathrm{Li}$ stem cells

\begin{tabular}{|ll|c|}
\hline Markers & Expressed in & Reaction \\
\hline CD31 endothelial marker & $\begin{array}{c}\text { epitheloid and vascular tumors, } \\
\text { histiocytic malignancy, plasmacytoma }\end{array}$ & - \\
\hline CD34 endothelial & sarcoma, histiocytoma, meningioma, & \\
and hemopoietic stem cell marker & neurofibroma, schwannoma, thyroid & - \\
& sarcoma, hematopoietic stem cells & \\
\hline S100 neurogen marker & lipoblast, retinoblastoma, melanoma, & \\
& neurofibroma, peripheral nerve sheath & \\
& tumor, paraganglioma, histiocytoma, & - \\
& clear cell sarcoma & \\
\hline Vimentin mesenchymal marker & colon cancer, esophageal & \\
& adenocarcinoma, gastric camcer, & \\
& breast cancer & \\
& stem cells & \\
& & \\
& & \\
& &
\end{tabular}

Cytogenetic characterization of $\mathrm{Hu} / \mathrm{Li}$ stem cell line was performed by Dr. Balazs Dezso, Institute of Pathology, University of Debrecen. 